\title{
MONITORING OF ENERGY GAIN AND EROSION PROTECTION OF CORN AND TALL WHEATGRASS CROPS IN THE CONDITIONS OF THE CZECH REPUBLIC
}

\begin{abstract}
Marek Kopecký, Faculty of Agriculture, University of South Bohemia in České Budějovice, Studentská 668, České Budějovice 37005, Czech Republic, kopeckymarek@ seznam.cz

Jaroslav Bernas, Faculty of Agriculture, University of South Bohemia in České Budějovice, Studentská 668, České Budějovice 37005, Czech Republic, bernas@zf.jcu.cz (corresponding author)

Ladislav Kolář, Faculty of Agriculture, University of South Bohemia in České Budějovice, Studentská 668, České Budějovice 37005, Czech Republic, kolar@zf.jcu.cz

Pavlína Hloucalová, Department of Animal Nutrition and Forage Production, Faculty of Agronomy, Mendel University in Brno, Zem`ed`elská 1/1665, Brno CZ 613 00, Czech Republic, pavel.horky@ mendelu.cz

With the growing energy demand of the society and the increased requirements for ecological aspects of obtaining and utilizing energies, renewable energy sources have been getting to the forefront. In the conditions of Central Europe, transformation of biomass to biogas through anaerobic digestion appears to be promising. The article describes the results of a field experiment carried out in an experimental site of the University of South Bohemia in České Budějovice (South Bohemia, Czech Republic). The goal of the article is to compare the conventionally grown corn (Zea mays L., hybrid Simao), the areas of which have increased considerably as a result of the development of biogas stations, and the alternative perennial grass called tall wheatgrass (Elymus elongatus subsp. ponticus cv. Szarvasi-1), which is, according to the literature, well positioned to replace corn. The harvests of the plants took place in 2013-2015, and tall wheatgrass was cut twice per season. A number of aspects - dry phytomass yield, specific methane yield and hectare methane yield - were monitored. In addition, the long-term soil loss by water erosion was calculated through the Universal Soil Loss Equation for both species of energy crops. In terms of yield parameters and methane production, better results were achieved by corn, given the average energy gain $238 \mathrm{GJ} \cdot \mathrm{ha}^{-1}$ as compared to $126 \mathrm{GJ} \cdot \mathrm{ha}^{-1}$ for tall wheatgrass. The protection of the soil surface from water erosion by corn appears to be insufficient and, in this criterion, it absolutely lags behind the anti-erosion abilities of tall wheatgrass, which protects soil incomparably better.
\end{abstract}

Keywords: corn, erosion, methane, tall wheatgrass, yield

\section{INTRODUCTION}

The growth of the world population is accompanied by a growing energy demand. A significant part of the consumption of energy sources is covered by fossil fuels, the combustion of which contributes to the environmental pollution and results in an increased content of greenhouse gases in the atmosphere (Moutinho et al., 2016). The use of renewable energy sources (RES), which are more environmentally friendly and bring new employment opportunities, may help to reduce the climate change (Dvořák et al., 2017). According to Eurostat (2017), the share of RES in the gross final energy consumption amounted to $15.1 \%$ in the Czech Republic in 2015, which is more than the target value set for 2020 (13\%). Despite that, the Czech Republic ranked below the EU28 average (16.7\%).

In the conditions of Central Europe, energy from plant biomass offers a huge potential (Bernas et al., 2015). Although organic waste should be preferably used for ecological power engineering, the areas of plants specially grown for power engineering have been enlarged in recent years (Lewandowski et al., 2003). In the Czech Republic, a large number of plants like that have been grown and may be used in numerous ways (Kopecký et al., 2017). However, the greatest progress was achieved in the field of technologies of biomass transformation to biogas through anaerobic digestion (Martinát et al., 2013). Biogas stations (BGS) have currently been used as stable sources of electric and thermal energy without burdening the environment by emissions (Mysáková et al., 2016), thus helping to mitigate negative consequences of the accruing greenhouse effect (Moudrý et al., 2013). A large number of BGS have been built in Europe, particularly in Germany, Denmark, Austria and Sweden, in recent past (Bacenetti et al., 2013). In 2015, there were 507 BGS with the total installed power of $358 \mathrm{MW}$ in the Czech Republic, and biogas had $24.7 \%$ share from among all RES (Czech Biogas Association, 2016).

Copyright (C) 2017 The Authors. Published by Aleksandras Stulginskis University. This is an open-access article distributed under the terms of the Creative Commons Attribution License (CC-BY 4.0), which permits unrestricted use, distribution, and reproduction in any medium, provided the original author and source are credited. 
One of the most prevalent energy crops is corn (Zea mays L.) which is, however, often perceived as a plant burdening the environment. This includes, for example, its influence on the climate through nitrogen oxides released after the application of mineral fertilizers, or pollution of surface waters by nitrates (Donner and Kucharik, 2008). Objectors to its excessive cultivation on arable land also argue that it competes other food or fodder crops (Emmann et al., 2012). One of the most significant negatives of the cultivation of corn is a large risk of water erosion (Vogel et al., 2016). Since erosion mostly affects the top soil layer, which is the most fertile, erosion is a factor considerably reducing the production and non-production potential of soil (Blanco-Canqui and Lal, 2008). In the Czech Republic, there are specific conditions for water erosion, particularly due to the size of field units, which are the largest in Europe. The farming methods used in the past caused the destruction of numerous hydrographic and landscape features that prevented accelerated erosion efficiently. In the Czech Republic, more than $50 \%$ of the area of arable land have been threatened by water erosion (Novotný et al., 2014).

Suitability of other plants that are more environmentally friendly has currently been assessed (Mast et al., 2014). In environmental terms, it is appropriate to grow perennial plants. Such plants still have an irreplaceable role in the feed industry (Hloucalová et al., 2016), but they also have been increasingly utilized in ecological power engineering (Kopecký et al., 2015). Replacement of annual energy crops, such as corn, by perennial plants contributes to the sustainability of biogas production in the future (Kiesel and Lewandowski, 2017). Various species from the family Poaceae may be used (Konvalina et al., 2014a). Dickeduisberg et al. (2017) recommends tall wheatgrass (Elymus elongatus), which is regarded as a crop that may match corn in terms of yields. An advantage of grasses over annual plants is their year-long protection of soil from torrential rain and wind, so they may also be recommended for locations that are soil erosion vulnerable (Dumbrovský et al., 2014). They also enrich soil by organic matter, which makes the topsoil more resistant to erosion (Kopecký et al., 2016) and enables the plants to utilize moisture more effectively (Konvalina et al., 2014b). The vegetation factor is, in terms of arable land management in relation to erosion vulnerability, together with the use of anti-erosion measures, the only factor that is directly controllable (Novotný et al., 2014).

The goal of the article is to compare conventionally grown corn and perennial energy grass called tall wheatgrass in terms of their yield potential, methane production and energy gain in their cultivation for the purpose of biogas production, and to determine the erosion vulnerability of soil by water erosion in the stands of those plants at the experimental site of the University of South Bohemia in České Budějovice. The field experiments took place from 2013 to 2016.

\section{METHODOLOGY}

The field part of the research took place at the experimental site of the University of South Bohemia in České Budějovice (Czech Republic). The habitat and weather characteristics in the course of the experiment are shown in Tab. 1 and Tab. 2.

Table 1. Annual and seasonal climate of the years 2013-2016 at the experimental site of České Budějovice

\begin{tabular}{ccccc}
\hline Year & Average temperature $\left({ }^{\circ} \mathrm{C}\right)$ & $\begin{array}{c}\text { Deviation from } \\
\text { long-term average } \\
\text { temperature }\left({ }^{\circ} \mathrm{C}\right)\end{array}$ & Precipitation (mm) & $\begin{array}{c}\text { Deviation from } \\
\text { long-term average } \\
\text { precipitation }(\mathrm{mm})\end{array}$ \\
\hline 2013 & 9.1 & +0.8 & 685.4 & +165.4 \\
\hline 2014 & 10.2 & +1.9 & 595.9 & +75.9 \\
\hline 2015 & 10.5 & +2.2 & 487.7 & -32.3 \\
\hline 2016 & 10.5 & +2.2 & 689.5 & +169.5 \\
\hline
\end{tabular}

Table 2. Habitat characteristics

\begin{tabular}{cc}
\hline Altitude (MSL) & 400 \\
\hline Agricultural production region & grain-growing \\
\hline Soil texture class & medium heavy-textured soil \\
\hline Soil type & pseudogley cambisoil \\
\hline $\mathrm{pH} \mathrm{H} \mathrm{O}$ & 6.1 \\
\hline $\mathrm{pH} \mathrm{KCl}$ & 5.6 \\
\hline GPS coordinates & $48^{\circ} 97^{\prime} 44.13^{\prime \prime} \mathrm{N}, 14^{\circ} 44^{\prime} 88.37^{\prime \prime} \mathrm{E}$ \\
\hline
\end{tabular}

Before sowing the perennial tall wheatgrass (Elymus elongatus subsp. ponticus cv. Szarvasi-1), the plot was fertilized with $200 \mathrm{~kg}$ of ammonium sulphate per hectare, $100 \mathrm{~kg}$ of ammonium nitrate with dolomite per hectare, $300 \mathrm{~kg}$ of triple superphosphate per hectare and $60 \mathrm{~kg}$ of potassium chloride per hectare. On 30 August 2013, the seeds were sown in four micro-plots sized $8 \times 1.25 \mathrm{~m}$. Early in the growing seasons of 2014, 2015 and 2016, the plots were fertilized with $300 \mathrm{~kg}$ of ammonium sulphate per hectare, $60 \mathrm{~kg}$ of triple superphosphate per hectare and $60 \mathrm{~kg}$ of potassium chloride per hectare. After the first harvest, $150 \mathrm{~kg}$ of ammonium nitrate per hectare were also applied. The plants were harvested twice in the vegetation seasons (3 June 2014, 30 September 2014, 12 June 2015, 1 October 2015, 2 June 2016, 13 September 2016) at the stage when dry matter constituted $30-33 \%$ of the phytomass content. The plants were harvested with a finger bar cutter at the height of $6 \mathrm{~cm}$.

The corn (Zea mays L., hybrid Simao) was sown on 15 May 2014, 17 April 2015 and 10 May 2016. During the sowing, the following fertilizes were applied: $220 \mathrm{~kg}$ of ureastabil per hectare, $190 \mathrm{~kg}$ of triple superphosphate per hectare and $100 \mathrm{~kg}$ of potassium chloride. Further $115 \mathrm{~kg}$ of ureastabil per hectare were added into the crop stand during the stage 
of growth. Corn was harvested at the time corresponding to the second harvests of tall wheatgrass at a height approximately $15 \mathrm{~cm}$ above the ground.

The harvested phytomass of both the crops was dried at $60^{\circ} \mathrm{C}$ to reach a constant weight, which was followed by the calculation of the dry matter yield (DMY). Every year, samples of the plants were ensilaged and underwent an analysis of gas development from the substrate through incubation in a medium in a certified chemical and microbiological laboratory where the specific methane yield (SMY) was identified. As for Elymus elongatus, only the second cutting was always analysed. The SMY value was multiplied by the total yield in the given year, thus determining the methane hectare yield (MHY).

The tested substrate was incubated in the digestate from the fermenter of the biogas station for which it is certain that it does not show any abnormal values of acids, lowered $\mathrm{pH}$, etc. A mixed digestate from fermenters of various biogas stations that use various "nourishment" for the bacteria, namely corn, grass, cow manure slurry, etc., was used. A certain quantity of homogenized substrate was added to the inoculum prepared as stated above, and was incubated in the anaerobic environment at the temperature of $40{ }^{\circ} \mathrm{C}$ until the potential of the substrate was fully used up. The gas was collected in a special measuring flask from which the results were read. On the way to the flask, gas was bubbled through a solution of Sodium hydroxide, capturing carbon dioxide and resulting in methane production with a small error caused by an effect of minority gases not captured in the hydroxide. The total quantity of such gases is below $2 \%$. The inoculum itself was used as a blind sample. The quantity of the gas produced in the blind test was deducted from the substrate results.

Based on the obtained information about the methane production ability and yields, we calculated MHY and energy gain (E) by using the formula:

$$
\mathrm{E}=\mathrm{HHV} \cdot \mathrm{MHY}
$$

E... energy gain $\left(\mathrm{MJ} \cdot \mathrm{ha}^{-1}\right)$

HHV ... higher heating value of methane $\left(39.8 \mathrm{MJ} \cdot \mathrm{m}^{-3}\right.$, Blok and Nieuwlaar, 2017)

MHY ... methane hectare yield $\left(\mathrm{m}^{3} \cdot \mathrm{ha}^{-1}\right)$

This was followed by a calculation of the long-term average soil loss by water erosion for the site conditions at the experimental site in České Budějovice through the Universal Soil Loss Equation (Wischmeier and Smith, 1978):

$$
\mathrm{G}=\mathrm{R} \cdot \mathrm{K} \cdot \mathrm{L} \cdot \mathrm{S} \cdot \mathrm{C} \cdot \mathrm{P}\left(\mathrm{t} \cdot \mathrm{ha}^{-1} \cdot \mathrm{year}^{-1}\right)
$$

G... the computed soil loss per unit area, expressed in the units selected for $\mathrm{K}$ and for the period selected for $\mathrm{R}$

$\mathrm{R}$... the rainfall and runoff factor

K... the soil erodibility factor

L... the slope-length factor

S... the slope-steepness factor

C... the cover and management factor

P... the support practice factor

Based on the application called Erosion Control Calculator (Research Institute for Soil and Water Conservation, 2017), the R-factor was 50.14. The other factors were derived according to the methodology of Janeček et al. (2012). The $\mathrm{K}$-factor value was determined on the basis of the main soil unit and amounted to 0.38. Depending on the length and the slope steepness, the L-factor (tall wheatgrass 1.4745 , corn 1.785$)$ and the S-factor (0.9149) were determined. The C-factor of tall wheatgrass is 0.01 , the $\mathrm{C}$-factor of corn is 0.72 due to its lower ability to protect the soil surface. The P-factor amounted to 1 - without anti-erosion measures.

Multiplying the $\mathrm{G}$ value and the size of the area that would be required for the energy gain of $1 \mathrm{TJ}$ resulted in the soil quantity that would be theoretically carried away by water erosion in connection with gaining this amount of energy in the cultivation of the examined energy crops in the given plot.

\section{RESULTS AND DISCUSSION}

DMY values are shown in Figure 1. Higher average yields $\left(14.5 \mathrm{t} \cdot \mathrm{ha}^{-1}\right)$ were found in corn. These yields correspond roughly to the figures reported by Corcoran et al. (2016). In his experiment (in Ireland), a yield amounting to approximately $12.6 \mathrm{t} \cdot \mathrm{ha}^{-1} \mathrm{DM}$ was achieved with a similar $\mathrm{N}$ fertilization intensity. However, literature often states considerably higher yields exceeding $20 \mathrm{t} \cdot \mathrm{ha}^{-1} \mathrm{DM}$ (Biom.cz, 2013). In our experiment, the reason for a lower average yield is especially the abnormally dry and warm weather in 2015 . Tall wheatgrass was able to withstand such weather better, reaching the yield that was only slightly below the average in that year. However, it also did not achieve its yield potential presented in literature. Depending on the local conditions and farming management, the yields may range from $5 \mathrm{t} \cdot \mathrm{ha}^{-1} \mathrm{DM}$ to more than $20 \mathrm{t} \cdot \mathrm{ha}^{-1} \mathrm{DM}$; yield examples are reported e.g. by Csete et al. (2011), Mast et al. (2014) or Janowszky and Janowszky (2009). 


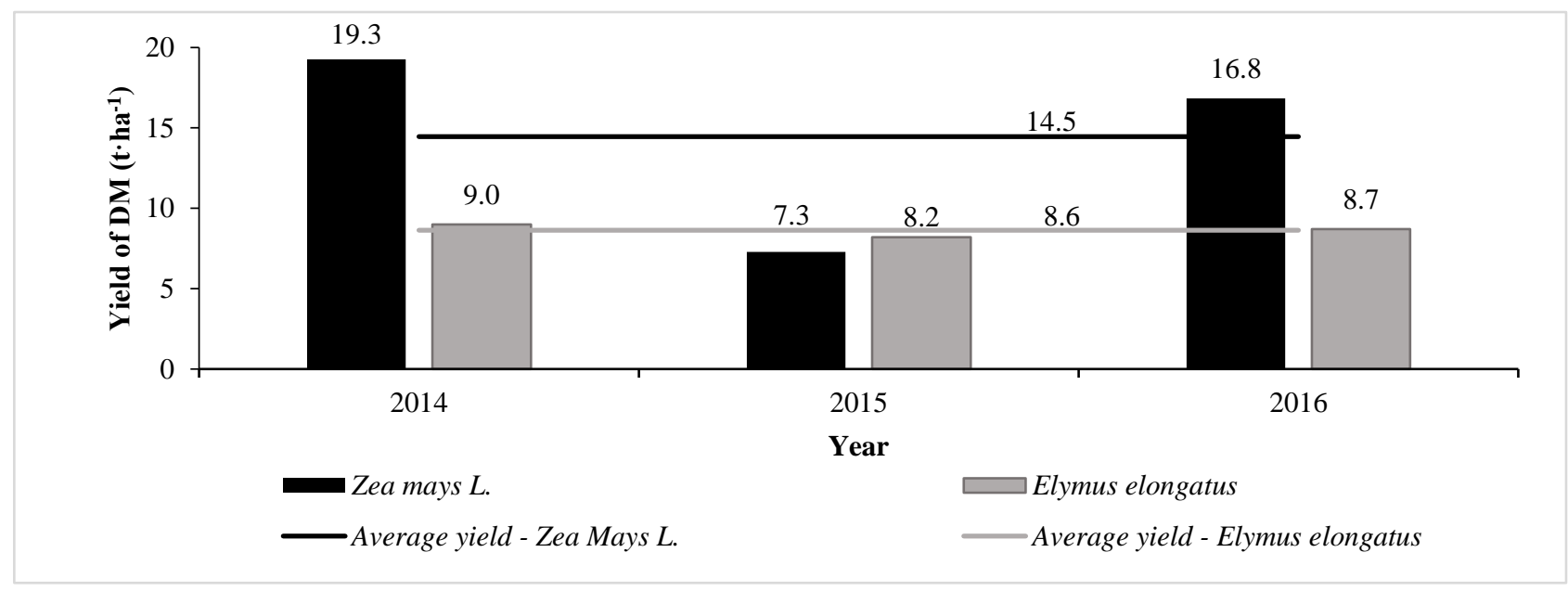

Figure 1. Yield of energy crops

A higher methane production was found in corn (Tab. 3) - namely by $49 \mathrm{~m}^{3} \cdot \mathrm{t}^{-1} \mathrm{DM}$ on average. Comparison of the biogas and methane production data with the data published in literature is problematic due to the different conditions and methods of determination (Müller and Frommert, 2002). However, e.g. Al Seadi et al. (2008) reports only $320 \mathrm{~m}^{3} \cdot \mathrm{t}^{-}$ ${ }^{1} \mathrm{DM}$ for corn although higher values are often reported. Dickeduisberg et al. (2017) dealt with the production of methane from tall wheatgrass in detail. Particularly due to the considerably higher yields of the matter per hectare in his experiment with the crop cut twice per season, MHY ranged from 4623 to $6778 \mathrm{~m}^{3} \cdot \mathrm{ha}^{-1}$, depending on the stubble height and the seed origin. This is substantially more than the yield achieved in our experiment. However, except for 2015, these values did not exceed the MHY achieved for corn in the experiment. Despite that, we are aware of even higher MHY, reaching almost $9000 \mathrm{~m}^{3} \cdot \mathrm{ha}^{-1}$, achieved for corn in the conditions of the Czech Republic (Biom.cz, 2013).

Table 3. Methane production and energy gain

\begin{tabular}{c|cccc|cccc}
\hline & \multicolumn{4}{c}{ Elymus elongatus } & \multicolumn{4}{c}{ Zea mays L. } \\
\cline { 2 - 9 } & 2014 & 2015 & 2016 & Average & 2014 & 2015 & 2016 & Average \\
\hline SMY $\left(\mathrm{m}^{3} \cdot \mathrm{t}^{-1} \mathrm{DM}\right)$ & 372 & 333 & 397 & 367 & 388 & 423 & 438 & 416 \\
MHY $\left(\mathrm{m}^{3} \cdot \mathrm{ha}^{-1}\right)$ & 3348 & 2734 & 3453 & 3178 & 7470 & 3086 & 7369 & 5975 \\
E $\left(\mathrm{GJ}^{-} \cdot \mathrm{ha}^{-1}\right)$ & 133 & 109 & 137 & 126 & 297 & 123 & 293 & 238 \\
\hline
\end{tabular}

The computed soil loss per unit area for corn and tall wheatgrass was 22.40 , respectively $0.26 \mathrm{t} \cdot \mathrm{ha}^{-1} \cdot \mathrm{year}^{-1}$. Given the ascertained average E value, the energy gain of $1 \mathrm{TJ}$ would theoretically require 4.2 ha of corn or 7.9 ha of tall wheatgrass. Although the area of tall wheatgrass would have to be almost twice as large as the area of corn in order to reach the same energy gain, the risk of water erosion is considerably lower for this perennial grass. While $94.21 \mathrm{t}$ of soil would be carried away by water erosion from a corn field sized 4.2 ha according to the calculation based on the Universal Soil Loss Equation, only $2.03 \mathrm{t}$ of soil would be carried away from an area covered by tall wheatgrass despite the larger size. According to Prochnow et al. (2009), grass cover provides excellent anti-erosion protection contrary to wide-row crops, which was also confirmed in this experiment.

\section{CONCLUSION}

Despite certain data published in literature, the information about a considerable yield potential of tall wheatgrass, which may, according to the available data, exceed even the yield of widely cultivated corn, has not been confirmed. In the course of the experiment, tall wheatgrass showed lower average DMY (8.6 vs. $\left.14.5 \mathrm{t} \cdot \mathrm{ha}^{-1}\right)$, SMY $\left(367 \mathrm{vs} .416 \mathrm{~m}^{3} \cdot \mathrm{t}^{-1}\right.$ DM) and MHY (3178 vs. $5975\left(\mathrm{~m}^{3} \cdot \mathrm{ha}^{-1}\right)$ than corn. Nevertheless, grass has a number of important ecological functions in the landscape. It follows from the research that due to its anti-erosion properties it provides almost perfect protection of the soil surface, which is confirmed by a calculation based on the Universal Soil Loss Equation. G value was extremely low $\left(0.26 \mathrm{t} \cdot \mathrm{ha}^{-1} \cdot\right.$ year $\left.^{-1}\right)$ for tall wheatgrass versus corn $\left(22.4 \mathrm{t} \cdot \mathrm{ha}^{-1} \cdot \mathrm{year}^{-1}\right)$ in our case. On the size of the area that would be required for the energy gain of $1 \mathrm{TJ}$ by byla total soil loss $94.21 \mathrm{t}$ from a corn field, but just $2.03 \mathrm{t}$ from a tall wheatgrass field. This means soil saving about $98 \%$. In erosion vulnerable areas and less intensive farming systems, tall wheatgrass may be used as an alternative to the currently dominant corn.

\section{ACKNOWLEDGEMENTS}

This work was supported by the University of South Bohemia in České Budějovice (project No. GAJU 094/2016/Z).

\section{REFERENCES}

1. Al Seadi, T., Rutz, D., Prassl, H., Köttner, M., Finsterwalder, T., Volk, S., Janssen, R. 2008. Biogas Handbook. 1st ed., University of Southern Denmark, Denmark. 
2. Bacenetti, J., Negri, M., Fiala, M., González-García, S. 2013. Anaerobic digestion of different feedstocks: impact on energetic and environmental balances of biogas process. Science of the Total Environment, Vol. 463-464, pp. 541-551. https://doi.org/10.1016/j.scitotenv.2013.06.058

3. Bernas, J., Jelínková, Z., Moudrý, J. jr., Kopecký, M., Moudrý, J. 2015. Miscanthus - Possibility of greenhouse gas emission mitigation. MendelNet, pp. 183-188, Mendel University in Brno.

4. Biom.cz. 2013. Pěstování kukuřice na výrobu bioplynu (Cultivation of maize for biogas production). Available at http://biom.cz/cz/odborne-clanky/pestovani-kukurice-na-vyrobu-bioplynu (Accessed12/9/, 2017). [in Czech]

5. Blanco-Canqui, H., Lal, R. 2008. Principles of Soil Conservation And Management, 1st ed., Springer, Netherlands.

6. Blok, K., Nieuwlaar, E. 2017. Introduction to energy analysis. 2nd ed., Taylor \& Francis, New York.

7. Corcoran, E. M., O'Kiely, P., Gilland, T. J., Burke, J. I., Lynch, M. B. 2016. Maize yield and composition affected by rate and timing of nitrogen fertiliser and mulch type. The multiple roles of grassland in the European bioeconomy. Proceedings of the 26th General Meeting of the European Grassland Federation, pp. 445-447, NIBIO.

8. Csete, S., Stranczinger, S., Szalontai, B., Farkas, A., Pál, R. W., Salamon-Albert, E., ... Walcz, I. 2011. Tall Wheatgrass Cultivar Szarvasi-1 (Elymus elongatus subsp. ponticus cv. Szarvasi-1) as a Potential Energy Crop for Semi-Arid Lands of Eastern Europe. Sustainable Growth and Applications in Renewable Energy Sources, pp. 269-294, InTech.

9. Czech biogas association. 2016. National technology platform for biogas. Available at http://www.czba.cz (Accessed 2/7/, 2017).

10. Dickeduisberg, M., Laser, H., Tonn, B., Isselstein, J. 2017. Tall wheatgrass (Agropyron elongatum) for biogas production: Crop management more important for biomass and methane yield than grass provenance. Industrial Crops and Products, Vol. 97, pp. 653-663. https://doi.org/10.1016/j.indcrop.2016.12.055

11. Donner, S. D., Kucharik, C. J. 2008. Corn-based ethanol production compromises goal of reducing nitrogen export by the Mississippi River. Proceedings of the National Academy of Sciences 105(11), pp. $4513-4518$. https://doi.org/10.1073/pnas.0708300105

12. Dumbrovský, M., Sobotková, V., Šarapatka, B., Chlubna, L., Vachalová, R. 2014. Cost-effectiveness evaluation of model design variants of broad-base terrace in soil erosion control. Ecological Engineering 68, pp. $260-269$. https://doi.org/10.1016/j.ecoleng.2014.03.082

13. Dvořák, P., Martinát, S., Van der Horst, D., Frantál, B., Turečková, K. 2017. Renewable energy investment and job creation; a cross-sectoral assessment for the Czech Republic with reference to EU benchmarks. Renewable and Sustainable Energy Reviews, Vol. 69, pp. 360-368. https://doi.org/10.1016/j.rser.2016.11.158

14. Emmann, C. H., Schaper, C., Theuvsen, L. 2012. Der Markt für Bioenergie 2012. German Journal of Agricultural Economics, Vol. 61(1), pp. 93-112.

15. Eurostat. 2017. Energy from renewable sources. Available at http://ec.europa.eu/eurostat/documents/2995521/7905983/814032017-BP-EN.pdf/af8b4671-fb2a-477b-b7cf-d9a28cb8beea (Accessed 5/9/, 2017).

16. Hloucalová, P., Novotná, M., Hortová, M., Kopecký, M., Horký, P., Skládanka, J. 2016. Effect of sown pastures on nitrogenous substance content in the forage. MendelNet, pp. 79-83, Mendel University in Brno.

17. Janeček, M., Dostál, T., Kozlovsky-Dufková, J., Dumbrovský, M., Hůla, J., Kadlec, V., ... Vlasák, J. 2012. Ochrana zemědělské půdy pred erozí: Metodika (Protection of agricultural land against erosion: Methodology), 1st ed., Czech University of Life Sciences Prague., Czech Republic. [in Czech]

18. Janowszky, J., Janowszky, Z. 2007. A Szarvasi-1 energiafü fajta - egy új növénye a mezőgazdaságnak és az iparnak (Szarvasi-1 energy grass - a novel crop for the agriculture and industry). Tasi, J. A magyar gyepgazdálkodás 50 éve Gödöllő, 89-92, Szt. István Egyetem. (in Hungary)

19. Kiesel, A., Lewandowski, I. 2017. Miscanthus as biogas substrate-Cutting tolerance and potential for anaerobic digestion. Gcb Bioenergy, Vol. 9(1), pp. 153-167. https://doi.org/10.1111/gcbb.12330

20. Konvalina, P., Moudrý, J., Suchý, K., Capouchová, I., Janovská, D. 2014a. Diversity of carbon isotope discrimination in genetic resources of wheat. Cereal Research Communications, Vol. 42(4), pp. 687-699. https://doi.org/10.1556/CRC.2014.0002

21. Konvalina, P., Stehno, Z., Capouchová, I., Zechner, E., Berger, S., Grausgruber, H., Janovská, D., Moudrý, J. 2014b: Differences in Grain/Straw Ratio, Protein Content and Yield in Landraces and Modern Varieties of Different Wheat Species Under Organic Farming. Euphytica, Vol. 199, pp. 31-40. https://doi.org/10.1007/s10681-014-1162-9

22. Kopecký, M., Bernas, J., Moudrý, J. jr., Kobes, M. 2015. Germination of Selected Grass Species in Water Stress Condition. SEED AND SEEDLINGS. XII. Scientific and technical seminar, pp. 216-221, Czech University of Life Sciences Prague.

23. Kopecký, M., Kolár̆, L., Borová-Batt, J. 2016. The new method of determination of the quantity and quality of primary soil organic matter and humus. Proceedings from International Conference Soil - the non-renewable environmental resource, pp. 135-142, Mendel University in Brno.

24. Kopecký, M., Moudrý, J. jr., Hloucalová, P., Bernas, J., Váchalová, R., Kyptová, M. 2017. Germination of seeds of selected energy grasses under water stress. SEED AND SEEDLINGS. XIII., pp. 187-192, Czech University of Life Sciences Prague.

25. Lewandowski, I., Scurlock, J. M., Lindvall, E., Christou, M. 2003. The development and current status of perennial rhizomatous grasses as energy crops in the US and Europe. Biomass and bioenergy, Vol. 25(4), pp. 335-361. https://doi.org/10.1016/S09619534(03)00030-8

26. Martinát, S., Dvořák, P., Frantál, B., Klusáček, P., Kunc, J., Kulla, M., Mintálová, T., Navrátil, L., van der Horst, D. 2013. Spatial consequences of biogas production and agricultural changes in the Czech Republic after EU accession: mutual symbiosis, coexistence or parasitism. Acta Universitatis Palackianae Olomucensis - Geographica, Vol. 44(2), pp. 75-92.

27. Mast, B., Lemmer, A., Oechsner, H., Reinhardt-Hanisch, A., Claupein, W., Graeff-Hönninger, S. 2014. Methane yield potential of novel perennial biogas crops influenced by harvest date. Industrial Crops and Products, Vol. 58, pp. $194-203$. https://doi.org/10.1016/j.indcrop.2014.04.017 
28. Mast, B., Lemmer, A., Oechsner, H., Reinhardt-Hanisch, A., Claupein, W., Graeff-Hönninger, S. 2014. Methane yield potential of novel perennial biogas crops influenced by harvest date. Industrial Crops and Products, Vol. 58, pp. $194-203$. https://doi.org/10.1016/j.indcrop.2014.04.017

29. Moudrý, J. jr., Jelínková, Z., Plch, R., Moudrý, J., Konvalina, P., Hyšpler, R. 2013. The emissions of greenhouse gases produced during growing and processing of wheat products in the Czech Republic. Journal of Food, Agriculture \& Environment, Vol. 11(1), pp. 1133-1136.

30. Moutinho, V., Madaleno, M., Silva, P. M. 2016. Which factors drive CO2 emissions in EU-15? Decomposition and innovative accounting. Energy Efficiency, Vol. 9(5), pp. 1087-1113. https://doi.org/10.1007/s12053-015-9411-x

31. Müller, W. R., Frommert, I. 2002. Existing standardised methods for anaerobic biodegradabilty testing. Harmonisation of anaerobic biodegradation, activity and inhibition assay, pp. 103-138, Institute for Environment and Sustainability.

32. Mysakova, D., Jac, I., Petru, M. 2016. Investment opportunities for family businesses in the field of use of biogas plants. $E+M$ Ekonomie a Management, Vol. 19(4), pp. 19-32. https://doi.org/10.15240/tul/001/2016-4-002

33. Novotný, I., Mistr, M., Papaj, V., Kristenová, H., Váňová, V., Kapická, J., Smolková, I. 2014. Př́ručka ochrany proti vodni erozi (Handbook of protection against water erosion). 1st ed., Ministry of Agriculture, Czech Republic. (in Czech)

34. Prochnow, A., Heiermann, M., Plöchl, M., Linke, B., Idler, C., Amon, T., Hobbs, P. J. 2009. Bioenergy from permanent grasslandA review: 1. Biogas. Bioresource technology, Vol. 100(21), pp. 4931-4944. https://doi.org/10.1016/j.biortech.2009.05.070

35. Research Institute for Soil and Water Conservation. 2017. Kalkulacka. Available at https://kalkulacka.vumop.cz/app/?.

36. Vogel, E., Deumlich, D., Kaupenjohann, M. 2016. Bioenergy maize and soil erosion-Risk assessment and erosion control concepts. Geoderma, Vol. 261, pp. 80-92. https://doi.org/10.1016/j.geoderma.2015.06.020

37. Wischmeier, W. H., Smith, D. D. 1978. Predicting rainfall erosion losses-a guide to conservation planning, 1st ed., Science and Education Administration, Maryland. 